Original Article

\title{
Analisis Kadar Interleukin-18 (Il-18) Serum dan Laju Filtrasi Glomerulus (GFR) Pada Obesitas Sentral dan Non Obesitas Sentral
}

\section{Analysis of Serum Interleukin-18 (Il-18) Levels and Glomerulus Filtration Rate (GFR) in Central Obesity and Non-Central Obesity}

\author{
Chika Pratiwi*1, Yuyun Widaningsih ${ }^{2}$, Liong Boy Kurniawan² \\ ${ }^{1}$ Magister Biomedik, Pascasarjana Universitas Hasanuddin, Makassar, Indonesia \\ ${ }^{2}$ Departemen Patalogi Klinis, Fakultas Kedokteran, Universitas Hasanuddin, Makassar, \\ Indonesia \\ (*chikapratw@gmail.com ,082322289893)
}

\begin{abstract}
ABSTRAK
Interleukin-18 adalah proinflmasi dihasilkan di glomerulus, meningkat pada keadaan sindrom metabolik diawali dengan obesitas, diekskresikan setelah cedera iskemik ginjal. IL-18 merupakan biomarker untuk mendiagnosis kerusakan ginjal akut. Laju filtrasi glomerulus (LFG) adalah salah satu biomarker untuk menilai fungsi ginjal. Tujuan menganalisis kadar IL-18 dan LFG pada obesitas dan non obesitas sentral. Penelitian cross sectional, Sampel terdiri atas 40 subjek obesitas sentral dan 33 subjek non obesitas sentral. Kadar IL-18 serum diperiksa dengan kit human IL-18 dengan metode ELISA dan kreatinin serum menggunakan alat Clinical Chemistry Analyzer ABX Pentra. Hasil penelitian tidak terdapat perbedaan bermakna terhadap kadar Interleukin-18 antara kelompok obesitas sentral dan non obesitas sentral $(\mathrm{p}=0,576)$ sedangkan nilai LFG pada subjek obesitas sentral memiliki nilai rerata yang lebih tinggi yaitu $103,17 \mathrm{ml} / \mathrm{min} / 1,73 \mathrm{~m} 2$ dibandingkan dengan subjek non obesitas sentral yaitu $96,47 \mathrm{ml} / \mathrm{min} / 1,73 \mathrm{~m} 2$ dan secara statistik tidak menunjukkan adanya perbedaan bermakna pada nilai LFG subyek laki-laki dengan obesitas sentral dan non obesitas sentral ( $\mathrm{p}=0,207)$. Pada analisis ini tidak ditemukan korelasi antara kadar IL-18 dan GFR pada kelompok obesitas dan non obesitas sentral $(\mathrm{r}=-0.047 \mathrm{p}=0,695)$.
\end{abstract}

Kata kunci : Interleukin-18 (IL-18), laju filtrasi glomerulus (LFG), obesitas Sentral, non obesitas sentral

\section{ABSTRACT}

Interleukin-18 is a proinflammatory produced in the glomerulus, increased in the setting of the metabolic syndrome preceded by obesity, excreted after ischemic kidney injury. IL-18 is a biomarker for diagnosing acute kidney damage. Glomerular filtration rate (GFR) is one of the biomarkers to assess kidney function. The purpose of analyzing the levels of IL-18 and GFR in obesity and non-obese central. Cross sectional study, the sample consisted of 40 centrally obese subjects and 33 non-central obese subjects. Serum IL-18 levels were checked with the human IL-18 kit using the ELISA method and serum creatinine using the ABX Pentra Clinical Chemistry Analyzer. The results showed that there was no significant difference in the levels of Interleukin-18 between the central obesity and non-central obesity groups ( $p=0.576)$, while the GFR value in centrally obese subjects had a higher mean value of 103.17 $\mathrm{ml} / \mathrm{min} / 1.73 \mathrm{~m} 2$ compared to non-central obesity subjects were $96.47 \mathrm{ml} / \mathrm{min} / 1.73 \mathrm{~m} 2$ and statistically did not show any significant difference in GFR values of male subjects with central obesity and noncentral obesity $(p=0.207)$. In this analysis, there was no correlation between IL-18 levels and GFR in the obese and non-central obesity groups $(r=-0.047 p=0.695)$.

Keywords : Interleukin-18 (IL-18), Glomerular Filtration Rate (GFR), Central Obesity, Non-Central Obesity.

https://doi.org/10.33860/jik.v15i2.451

(C) 2021 by the authors. Submitted for possible open access publication under the terms and conditions of the Creative

Commons Attribution (CC BY SA) license (https://creativecommons.org/licenses/by-sa/4.0/). 


\section{PENDAHULUAN}

Obesitas terdapat dua jenis yaitu obesitas general dan obesitas sentral. Obesitas general adalah obesitas dengan penumpukan lemak diseluruh tubuh. Obesitas sentral merupakan obesitas dengan penumpukan lemak terjadi pada daerah perut dan pinggang. Obesitas sentral juga dikenal sebagai obesitas sentral atau obesitas viseral. Obesitas sentral didapatkan dengan mengukur lemak viseral yang terdapat di daerah sekitar perut. Metode yang sering digunakan adalah pengukuran lingkar pinggang ${ }^{1}$.

Berdasarkan Riskesdas prevalensi obesitas sentral di Provinsi Sulawesi Selatan pada tahun 2013 sebesar 24,7\% pada usia perempuan $>18$ tahun menjadikan kota Makassar angka tertinggi ketiga untuk penderita obesitas sentral. Obesitas sentral berhubungan dengan sindrom metabolik ${ }^{2}$.

Kegemukan dan obesitas adalah salah

faktor risiko yang signifikan penelitian menunjukkan obesitas sebagai faktor risiko terjadinya End Stage Of Renal Disease (ESRD) dan Chronic Kidney Disease (CKD). Sebuah studi prospektif juga melaporkan obesitas berhubungan dengan risiko terjadinya CKD dan ESRD, mekanisme terjadinya gagal ginjal pada obesitas masih sulit dipahami dan masih bersifat spekulatif. Disamping faktor hemodinamik dan inflamsi, efek metabolik juga berhubungan dengan terjadinya obesitas ${ }^{3}$.

Penderita obesitas dengan penyakit ginjal kronik memiliki tingkat yang lebih tinggi untuk penurunan laju filtrasi glomerulus atau Glomerular Filtration Rate (GFR) dan lebih cepat mengalami End Stage Of Renal Disease (ESRD) pada individu obesitas dibandingkan dengan mereka yang memiliki berat badan normal ${ }^{4}$. GFR telah diterima secara luas sebagai indeks terbaik untuk menilai fungsi ginjal ${ }^{5}$.

Interleukin-18 diproduksi oleh berbagai tipe sel, misalnya : sel-sel Kupffer, fibroblas, kondrosit, makrofag, keratinosit, dan osteoblas. IL-18 juga diproduksi oleh tubulus proksimal, tepatnya di epital tubular ginjal, dan makrofag interstitial. IL-18 berperan aktif disejumlah penyakit ginjal, seperti: cedera reperfusi-iskemi, rejeksi transplantasi, dan infeksi saluran kemih. Kadar IL-18 secara fisiologi sangat rendah, namun dapat meningkat beberapa kali lipat pada pasien dengan cedera ginjal. Peningkatan IL-18 urin, terjadi akibat cedera di tubulus pasien dengan sepsis. Cedera yang ditimbulkan pada sel-sel tubular ginjal melalui berbagai mekanisme akan memicu respon inflamasi lokal, salah satu sitokin penting yang memodulasi proses inflamasi intra-renal adalah Interleukin 18 (IL-18), yang di sekresikan oleh sel-sel tubular yang cedera ${ }^{6}$.

Keadaan obesitas sentral yang membuat terjadinya peningkatan kadar proinflamator, terutama IL-18 adalah akibat inflamasi kronis yang terjadi dalam keadaan tersebut. Dalam proses inflamasi, umumnya tubuh mengeluarkan agen toksik dan enzim proteolitik untuk mengeliminasi protein dan menetralisasi stimulus asing dari tubuh. Bila proses pengeliminasian dan netralisasi berhasil, maka selanjutnya mediator-mediator proinflamasi yang diproduksi berapoptosis dan mengalami fagositosis oleh makrofag yang nantinya dibuang lewat drainase limfatik. Kelebihan asupan dan physical inactivity yang menyebabkan obesitas timbul ekspresi berbagai mediator-mediator pro-inflamasi terutama IL18 yang diduga meningkat kadarnya bila diikuti dengan kejadian sindrom metabolik ${ }^{7}$.

$$
\text { Laju Filtrasi Glomerulus }
$$

(LFG) adalah laju rata-rata penyaringan darah yang terjadi pada glomerulus ginjal ${ }^{8}$. Laju filtrasi glomerulus atau Glomerular Filration Rate (GFR) adalah salah satu biomrker untuk menilai fungsi ginjal yang terjadi di glomerulus, sedangkan IL-18 merupakan biomarker baru untuk mendiagnosis AKI. Ginjal merupakan organ yang dapat langsung dipengaruhi oleh obesitas, hipertensi maupun diabetes. Namun disfungsi ginjal pada obesitaas dapat terjadi sebelum terdapat hipertensi maupun diabetes ${ }^{910}$. Kelainan ginjal sebagai komplikasi obesitas disebut gangguan ginjal terkait obesitas atau obesity-related renal injury ${ }^{1112}$.

Berbagai penelitian epidemiologi menunjukkan bahwa obesitas meningkatkan resiko penyakit ginjal, namun sebagian besar penelitian tentang pro-inflamatori sitokin IL-18 dengan penurunan fungsi ginjal pada obesitas masih sangat terbatas, padahal pemahaman tentang kerusakan ginjal tahap dini pada dewasa muda dengan obesitas sentral sangat penting, untuk dilakukan interverensi dalam rangka mencegah kerusakan ginjal yang lebih lanjut. Hal tersebut mendorong peneliti untuk ditelitinya kadar Interleukin-18 dan laju filtrasi glomerulus pada obesitas sentral dan obesitas sentral untuk melihat seberapa besar tingkat 
inflamasi dan dampak yang diakibatkan oleh obesitas terhadap fungsi ginjal

\section{METODE PENELITIAN}

Jenis penelitian ini adalah jenis penelitian observational analitik dengan rancangan penelitian cross sectional. Subjek penelitian adalah semua orang dewasa yang mengalami obesitas sentral dan non obesitas di Kota Makassar. Obesitas sentral $=40$ orang dan Non obesitas sentral $=33$ orang. Penelitian ini telah mendapat persetujuan komite etik Fakultas Kedokteran Universitas Hasanuddin dengan nomor UH20100594.

Subjek penelitian yang memenuhi kriteria inklusi dilakukan pengambilan sampel darah vena sebanyak $3 \mathrm{ml}$. Pemeriksaan kadar Interleukin-18 mennggunakan metode ELISA dilakukan di laboratorium Biomolekuler dan Imunologi Fakultas Kedokteran Universitas Hasanuddin dan pemeriksaan kadar kreatinin serum di lakukan di Laboratorium Patologi Klinik Rumah Sakit Universitas Hasanuddin Makassar. Data diuji statistik dengan uji Mann whitney dan uji $t$ independent. Hasil dianggap signifikan secara statistik pada nilai $\mathrm{p}<0.05$.

\section{HASIL}

Hasil uji menunjukkan rerata umur pada subjek dengan obesitas sentral adalah 30,45 tahun $(\mathrm{SD}=5,54)$, sedangkan pada subjek non obesitas sentral adalah 28,54 tahun $(\mathrm{SD}=4,03)$. Rerata lingkar pinggang (LP) pada subjek obesitas sentral adalah 94,87 $\mathrm{cm}(\mathrm{SD}=11,82)$, sedangkan pada non obesitas sentral adalah $78,75 \mathrm{~cm}(\mathrm{SD}=5,78)$ (Tabel 1). Kesimpulan dari hasil tersebut adalah terdapat perbedaan yang bermakna ukuran LP antara subjek obesitas sentral dan non obesitas sentral $(p=<0,05)$ sedangkan pada variabel umur tidak terdapat perbedaan yang bermakna $(p=>0,05)$. Perbedaan Subjek Obesitas Sentral dan Non Obesitas Sentral dapat dilihat pada Tabel 2.

Perbedaan kadar IL-18 (Interleukin-18) dan GFR (Glomerular Filtration Rate) pada subjek obesitas sentral dan non obesitas sentral dapat dilihat pada Tabel 3. Rerata kadar IL-18 pada kelompok obesitas sentral 15,24 ng/L $(\mathrm{SD}=19,12)$ dan rerata non obesitas sentral $18,81 \mathrm{ng} / \mathrm{L}(\mathrm{SD}=17,95)$, sedangakan rerata nilai GFR pada obesitas sentral 103,17 $\mathrm{ml} / \mathrm{min} / 1,73 \mathrm{~m}^{2} \quad(\mathrm{SD}=24,74) \quad$ lebih tinggidibandingkan rerata pada kelompok non obesitas sentral 96,47 $\mathrm{ml} / \mathrm{min} / 1,73 \mathrm{~m}^{2}(\mathrm{SD}=19,49)$. Berdasarkan uji statistik menggunakan uji Mann-Whitney (IL18 dan GFR tidak terdistribusi normal) menunjukkan tidak terdapat perbedaan yang bermakna kadar IL-18 dan GFR pada subjek obesitas sentral dan non obesitas sentral $(p=>0,05)$.

Hasil uji korelasi Spearman's menunjukkan tidak terdapat hubungan yang bermakna antara kadar IL-18 dengan GFR $(p=0,695)$. Korelasi kadar IL-18 dengan GFR dapat dilihat pada Tabel 4 .

Tabel 1. Karateristik Subjek Penelitian

\begin{tabular}{cccc}
\hline Variabel & $\mathbf{N}=\mathbf{7 3}(\mathbf{\%})$ & Mean \pm SD & Median (Min - Max) \\
\hline Umur (tahun) & - & $29,58 \pm 4,97$ & $29(21-39)$ \\
Jenis kelamin : & $40(54,8 \%)$ & - & - \\
Laki-laki & $33(45,2 \%)$ & - & - \\
Perempuan & & & - \\
Kelompok : & $40(54,8 \%)$ & - & - \\
Obesitas sentral & $33(45,2 \%)$ & - & $85(68-136,50)$ \\
Non obesitas sentral & - & $87,58 \pm 12,48$ & $25,11(19,28-47,61)$ \\
LP $(\mathrm{cm})$ & - & $26,59 \pm 5,51$ & $65,5(48,70-80,00)$ \\
IMT $\left(\mathrm{kg} / \mathrm{m}^{2}\right)$ & - & $1,60,12 \pm 87,15$ & $1,61(0,08-1,84)$ \\
BB $(\mathrm{kg})$ & - & $16,40 \pm 18,52$ & $6,17(3,78-86,50)$ \\
TB $(\mathrm{cm})$ & - & $100,14 \pm 22,46$ & $98,70(60,28-160,00)$ \\
IL-18 $(\mathrm{ng} / \mathrm{L})$ &
\end{tabular}

Keterangan: Mean=Rata-rata, Min=Minimal, Max=Maksimal, SD=Standar Deviasi, LP=Lingkar pinggang, IMT=Indeks Massa Tubuh, IL-18=Interleukin-18, GFR=Glomerular Filtration Rate

Tabel 2. Perbedaan Subjek Obesitas Sentral dan Non Obesitas Sentral 


\begin{tabular}{cccc}
\hline \multirow{2}{*}{ Karateristik } & $\begin{array}{c}\text { Obesitas sentral } \\
(\mathbf{n}=\mathbf{4 0})\end{array}$ & $\begin{array}{c}\text { Non Obesitas Sentral } \\
(\mathbf{n = 3 3})\end{array}$ & \multirow{2}{*}{\begin{tabular}{c} 
Mean \pm SD \\
\cline { 2 - 3 }
\end{tabular}} \\
\cline { 2 - 3 } Uean \pm SD & $28,54 \pm 4,03$ & $0,112^{*}$ \\
LP (cm) & $30,45 \pm 5,54$ & $78,75 \pm 5,78$ & $0,000^{* *}$ \\
\hline
\end{tabular}

Keterangan : Mean=Rata-rata, $\mathrm{SD}=$ Standar Deviasi, $\mathrm{LP}=$ Lingkar pinggang, , $p=$ probabilitas.

*Uji Mann Whitney

**Uji t Independent

Tabel 3. Perbedaan kadar IL-18 (Interleukin-18), GFR (Glomerular Filtration Rate) pada subjek obesitas sentral dan non obesitas sentral

\begin{tabular}{cccccc}
\hline \multirow{2}{*}{ Variabel } & \multicolumn{2}{c}{ Obesitas sentral $(\mathbf{n = 4 0 )}$} & \multicolumn{2}{c}{ Non Obesitas Sentral $(\mathbf{n}=\mathbf{3 3})$} & $p$ \\
\cline { 2 - 5 } & $\begin{array}{c}\text { Median } \\
(\text { Min-Max })\end{array}$ & Mean \pm SD & $\begin{array}{c}\text { Median } \\
(\text { Min-Max })\end{array}$ & Mean \pm SD & \\
\hline IL-18 (ng/L) & $6,295(3,78-86,50)$ & $15,24 \pm 19,12$ & $5,64(4,28-60,33)$ & $17,81 \pm 17,95$ & $0,576^{*}$ \\
$\begin{array}{c}\text { GFR } \\
\left(\mathrm{ml} / \mathrm{min} / 1,73 \mathrm{~m}^{2}\right)\end{array}$ & $110(60,28-160,0)$ & $103,17 \pm 24,47$ & $92(66,0-158,0)$ & $96,47 \pm 19,49$ & $0,207^{*}$ \\
\hline
\end{tabular}

Sumber : Data Primer

Keterangan : Mean=Rata-rata, SD=Standar Deviasi, LP=Lingkar pinggang, IMT=Indeks Massa Tubuh, IL18=Interleukin-18, GFR=Glomerular Filtration Rate, $p=$ Probabilitas

*Uji Mann Whitney

**Uji t Independent.

Tabel 4. Korelasi Kadar Interleukin-18 (IL-18) dan GFR (Glomerular Filtration Rate) pada obesitas sentral dan non obesitas sentral

\begin{tabular}{|c|c|c|}
\hline Variabel & & IL-18 (ng/L) \\
\hline \multirow{3}{*}{$\begin{array}{c}\text { GFR } \\
\left(\mathrm{ml} / \mathrm{min} / 1,73 \mathrm{~m}^{2}\right)\end{array}$} & $\mathrm{n}$ & 73 \\
\hline & $r$ & $-0,047^{*}$ \\
\hline & $p$ & $0,695^{*}$ \\
\hline
\end{tabular}

Keterangan:

IL-18=Interleukin-18, GFR=Glomerular Filtration Rate, $\mathrm{n}=$ Jumlah, $\quad p=$ Probabilitas, $\quad r=$ Koefisien Korelasi..

\section{PEMBAHASAN}

Obesitas dikaitkan dengan peradangan kronis tingkat rendah yang dapat menyebabkan beberapa gangguan kesehatan seperti penyakit kardiovaskular (CVD), Diabetes Mellitus (DM), arthritis dan penyakit lainnya ${ }^{13} .{ }^{14}$. Obesitas perut yang lebih sering ditemukan pada pria daripada wanita merupakan sumber utama sitokin dan adipokin pro-inflamasi. Kelebihan lemak viseral dikaitkan dengan profil metabolik yang lebih buruk daripada penumpukan lemak tubuh lainnya ${ }^{14}$.

Keadaan obesitas sentral yang membuat terjadinya peningkatan kadar proinflamator, terutama IL-18 adalah akibat Interleukin-18 (IL-18) merupakan inflamasi kronis yang terjadi dalam keadaan tersebut. Inflamasi ditandai dengan penumpukan jaringan lemak atau sel-sel adiposa yang mengisi rongga-rongga kosong di dalam tubuh terutama pada rongga bagian abdominal yang disebut sebagai lemak viseral (lemak abdominal). Peningkatan produksi selsel adiposa dianggap sebagai protein atau stimulus asing oleh mekanisme imun tubuh. Mekanisme imun tubuh mengidentifikasi selsel adiposa ini berbahaya dan mengancam tubuh, sehingga menghasilkan respon imun yang diawali dengan produksi mediator proinflamasi seperti sitokin dan kemokin. Dalam proses inflamasi, umumnya tubuh mengeluarkan agen toksik dan enzim proteolitik untuk mengeliminasi protein dan menetralisasi stimulus asing dari tubuh. Bila proses pengeliminasian dan netralisasi berhasil, maka selanjutnya mediator-mediator proinflamasi yang diproduksi berapoptosis dan mengalami fagositosis oleh makrofag yang nantinya dibuang lewat drainase limfatik. Proses pengeliminasian dan netralisasi protein dan stimulus asing yang gagal membuat proses inflamasi tetap berlangsung dan produksi agen pro-inflamator terutama IL-18 terus meningkat, proses inilah yang disebut sebagai inflamasi kronis $^{7}$

anggota sitokin proinflamasi yang dikeluarkan 
dari sel mononuklear ${ }^{15}$. IL-18 merupakan anggota IL-1 yang diproduksi oleh berbagai tipe sel, misalnya : sel-sel Kupffer, fibroblas, kondrosit, makrofag, keratinosit, dan osteoblas. IL-18 juga diproduksi oleh tubulus proksimal, tepatnya di epital tubular ginjal, dan makrofag interstitial. IL-18 berperan aktif disejumlah penyakit ginjal, seperti: cedera reperfusida sel-sel tubular ginjal melalui berbagai mekanisme akan memicu respon inflamasi lokal, salah satu sitokin penting yang memodulasi proses inflamasi intra-renal adalah Interleukin 18 (IL-18), yang di sekresikan oleh sel-sel tubular yang cedera ${ }^{6}$.

Lingkar pinggang tidak mudah diturunkan karena lemak yang menumpuk tersimpan di jaringan adiposa perut sulit untuk dimetabolisme. Jaringan adiposa dapat mengeluarkan IL-18 yang menunjukkan adanya inflamasi sel dalam jaringan tersebut. Inflamasi pada sel, sama dengan kerusakan sel pada jaringan berkaitan dengan terganggunya proses metabolisme. Perubahan kualitas gaya hidup menjadi lebih baik, dapat dilihat dengan menurunnya kadar IL-18 dalam tubuh yang merupakan salah biomarker dari inflamasi.

Berdasarkan hasil penelitian, kelompok obesitas sentral menunjukkan kadar Interleukin-18 dalam darah memiliki nilai rerata yang lebih rendah yaitu 15,24 $(\mathrm{SD}=19,12)$ dibandingkan dengan subjek non obesitas sentral yaitu $17,81 \quad(\mathrm{SD}=17,95)$, meskipun nilai rerata kadar IL-18 pada obesitas sentral lebih rendah daripada non obesitas sentral nilai tersebut masih masuk ke dalam rentang nilai normal kadar IL-18 yaitu 5-64 $\mathrm{ng} / \mathrm{L}$ dan secara statistik tidak terdapat perbedaan bermakna pada subjek obesitas sentral dan non obesitas sentral $(p=0,576)$. Hal ini tidak sesuai dengan hipotesis bahwa pada subjek obesitas sentral kadar IL-18 lebih tinggi daripada non obesitas sentral. Tidak terjadi peningkatan kadar IL-18 pada subjek obesitas karena subjek yang digunakan adalah subjek yang digunakan pada penelitian ini merupakan orang sehat yang tidak dengan riwayat penyakit hipertensi, ginjal, DM dan penyakit lainnya yang dapat menyebabkan peningkatan kadar IL-18 pada serum. Hal ini juga didukung oleh penelitian ${ }^{16}$ peningkatan IL-18 serum dikaitkan dengan perkembangan diabetes tipe 2 yang tidak tergantung pada massa lemak. Temuan ini menunjukkan bahwa IL-18 serum lebih berhubungan dengan tingkat resistensi insulin daripada tingkat obesitas. Penelitian yang iskemi, rejeksi transplantasi, dan infeksi saluran kemih. Kadar IL-18 secara fisiologi sangat rendah, namun dapat meningkat beberapa kali lipat pada pasien dengan cedera ginjal. Peningkatan IL-18 urin, terjadi akibat cedera di tubulus pasien dengan sepsis. Cedera yang ditimbulkan pa

dilakukan oleh ${ }^{17}$, menjelaskan bahwa terdapat peningkatan kadar Interleukin-18 pada remaja obesitas sentral yang ditandai dengan adanya sindrom metabolik dibandingkan kelompok obesitas sentral tanpa sindrom metabolik dan secara statistik ditemukan perbedaan yang bermakna $(p=0,048)$.

Obesitas secara luas telah diakui sebagai faktor risiko penyakit kardiovaskular dan berbagai gangguan metabolik seperti penyakit diabetes mellitus. Selama ini perhatian yang ditujukan mengenai hubungan antar meningkatnya berat badan dan PGK sangat kurang, walaupun telah diketahui hubungan yang erat antara prevalensi PGK dengan faktorfaktor yang berkaitan dengan obesitas, seperti hipertensi, hiperglikemia, dislipidemia, inflamasi dan aterosklerosis. Faktor-faktor ini terjadi bersama-sama, khususnya bila terdapat kelebihan lemak viseral seperti yang dikenal sebagai sindrom metabolik. Selain itu, terdapat bukti yang sangat kuat bahwa lemak viseral merupakan faktor utama dari timbulnya semua kelainan yang berkaitan dengan sindrom metabolik, termasuk PGK. Meningkatnya kejadian PGK paralel dengan meningkatnya kejadian kelebihan berat badan dan obesitas. Selain menyebabkan meningkatnya biaya perawatan, komplikasi PGK meningkatkan morbiditas dan mortalitas ${ }^{18}$

Laju Filtrasi Glomerulus (LFG) adalah volume plasma yang dapat di bersihkan secara sempurna terhadap senyawa tertentu oleh ginjal dalam satu unit waktu. LFG telah diterima secara luas sebagai indeks terbaik untuk menilai fungsi ginjal. LFG dapat diperkirakan dengan mengukur kadar kreatinin serum dari pasien yang terduga dan atau memiliki faktor risiko gangguan fungsi ginjal. Salah satu penyebab yang dapat memepengaruhi nilai LFG adalah obesitas. Obesitas dapat menurunkan nilai LFG seseorang dengan mekanisme salah satunya adalah peningkatan kadar angiotensisn yang menyebabkan penurunan fungsi serta kerusakan ginjal ${ }^{19}$.

Hasil penelitian menunjukkan bahwa nilai Glomerular Filtration Rate (GFR) pada 
subjek obesitas sentral memiliki nilai rerata yang lebih tinggi yaitu 103,17 ( $\mathrm{SD}=24,47)$ dibandingkan dengan subjek non obesitas sentral yaitu $96,47(\mathrm{SD}=19,49)$ dan nilai rerata dari kedua subjek tersebut masih berada dalam rentang nilai normal GFR yaitu $>90$ $\left(\mathrm{ml} / \mathrm{min} / 1,73 \mathrm{~m}^{2}\right)$ dan secara statistik tidak menunjukkan adanya perbedaan bermakna $(p=0,207)$. Hal ini tidak sesuai dengan hipotesis bahwa GFR pada obesitas sentral lebih rendah daripada non obesitas sentral. Dalam hal ini tidak terjadi penurunan nilai GFR pada subjek obesitas karena subjek yang digunakan adalah orang sehat yang tidak dengan riwayat penyakit ginjal, DM ataupun penyakit lainnya yang dapat menyebabkan penurunan nilai GFR. ${ }^{4}$ menyatakan bahwa penderita obesitas dengan penyakit ginjal kronik memiliki tingkat yang lebih tinggi untuk penurunan laju filtrasi glomerulus atau Glomerulus Filtration Rate (GFR) dan lebih cepat mengalami End Stage Of Renal Disease (ESRD) pada individu obesitas dibandingkan dengan mereka yang memiliki berat badan normal. ${ }^{20}$ juga menyatakan bahwa peningkatan IMT atau obesitas dan penurunan fungsi ginjal terkait dengan faktor risiko berupa low-grade inflammation (seperti peningkatan $C$-reaktive protein, hemocysteinemia, peningkatan aktivitas simpatis, hiperfiltrasi karena resistensi insulin, serta peningkatan sitokin-sitokin) yang dapat menyebabkan aterosklerosis yang akan berujung pada penurunan laju filtrasi glomerulus.

Pada penelitian ini tidak ditemukan korelasi bermakna antara kadar Interleukin-18 dan GFR pada kelompok obesitas sentral dan non obesitas sentral ( $\mathrm{p}=0,695 r=-0,047)$. Hal ini tidak sejalan dengan penelitian yang dilakukan oleh ${ }^{21}$ yaitu terdapat korelasi yang signifikan antara kadar IL-18 dengan nilai e-GFR pada penderita nefropati diabetik dengan nilai $\mathrm{p}=$ $<0,001 \quad r=-0,077$, korelasi antara kadar Interleukin 18 dengan nilai e-GFR bernilai negatif, yang mana ini berarti bahwa hubungan anatara kadar IL-18 dengan nilai e-GFR berjalan berlawanan arah. Dengan kata lain, semakin tinggi kadar IL-18 penderita DM, maka semakin rendah nilai e-GFR. Perbedaan sampel yang digunakan pada kedua penelitian ini yaitu subjek obesitas dan non obesitas sentral dan subjek nefropati diabetik sehingga hasil analisis statistik yang diperoleh berbeda ${ }^{15}$ menyatakan bahwa IL-18 sangat erat kaitannya dengan diabetes maupun nefropati diabetik, karena IL-18 sejalan dengan patofisiologi DM berkembang menjadi nefropati diabetik.

Penelitian ini memiliki beberapa keterbatasan. Pertama, desain cross sectional yang digunakan tidak dapat menjelaskan kausalitas hasil penelitian ini. Kedua, sebaran jenis kelamin yang tidak seimbang sehingga dapat mempengaruhi hasil secara statistik. Ketiga, variabel yang dapat mempengaruhi hasil seperti diet hipokaloik dan aktivitas fisik. Keempat, faktor-faktor yang dapat mempengaruhi risiko kardiovaskular tidak di analisis. Kelima, peneliti tidak memperkirakan lama obesitas sentral pada subjek seperti mengetahui durasi obesitas bahwa subjek telah mengalami obesitas sentral dalam beberapa tahun terakhir. Faktor-faktor seperti derajat obesitas dan lamanya obesitas sangat mempengaruhi hasil ${ }^{22}$.

\section{KESIMPULAN DAN SARAN}

Peneliti menyimpulkan bahwa tidak terdapat perbedaan bermakna kadar Interleukin18 pada subjek dengan dan tanpa obesitas sentral. Hasil analisis menunjukkan tidak terdapat perbedaan bermakna nilai GFR pada subjek dengan dan tanpa obesitas sentral dan berdasarkan uji korelasi tidak terdapat korelasi yang bermakna antara kadar Interleukin 18 (IL18) dengan nilai Laju Filtrasi glomerulus atau Glomerular Filtration Rate (GFR) pada subjek obesitas sentral dan non obesitas sentral.

\section{DAFTAR PUSTAKA}

1. Janssen I, Katzmarzyk PT, Boyce WF, King MA, Pickett W. Overweight and obesity in Canadian adolescents and their associations with dietary habits and physical activity patterns. Journal of Adolescent Health. 2004;35(5):360-7.

2. Taslim NA, Asfar M, Angriawan S, ... IbWCSR IDI Kota Makassar, Menuju Makassar Sehat melalui Peningkatan Konsumsi Ikan, Sayur dan Buah 1Nurpudji. Panrita AbdiJurnal ... 2018;2(2):127-34.

3. Norli Marwyne MN, Loo CY, Halim AG, Norella K, Sulaiman T, Zaleha MI. Estimation of glomerular filtration rate using serum cystatin $\mathrm{C}$ in overweight and obese subjects. Medical Journal of Malaysia. 2011;66(4):313-7.

4. de Boer IH, Katz R, Fried LF, Ix JH, Luchsinger J, Sarnak MJ, et al. Obesity and Change in Estimated GFR Among Older Adults. American Journal of Kidney Diseases. 2009;54(6):1043-51.

5. Rita C. Role Of Cystatine $\mathrm{C}$ in Kidney 
Function Assesment. In: KONAS \& PIT VI PDS PATKLIN. 2007. p. 222-5.

6. Ikrar T, States U. Interleukin 18, Biomarkers of Acute Kidney Injury. 2017;(March).

7. Monteiro R, Azevedo I. Chronic inflammation in obesity and the metabolic syndrome. Mediators of Inflammation. 2010;2010(Atp Iii).

8. Verdiansah. Pemeriksaan Fungsi Ginjal. CDK. 2016;43(2):148-54.

9. Graf L, Reidy K, Kaskel FJ. Nutrition management in childhood kidney disease: An integrative and lifecourse approach. Pediatric Nephrology, Seventh Edition. 2015;341-60.

10. Savino A, Pelliccia P, Chiarelli F, Mohn A. Obesity-related renal injury in childhood. Hormone Research in Paediatrics. 2010;73(5):303-11.

11. Wahba IM, Mak RH. Obesity and obesityinitiated metabolic syndrome: Mechanistic links to chronic kidney disease. Clinical Journal of the American Society of Nephrology. 2007;2(3):550-62.

12. Wang Y, Beydoun MA. The obesity epidemic in the United States - Gender, age, socioeconomic, racial/ethnic, and geographic characteristics: A systematic review and metaregression analysis. Epidemiologic Reviews. 2007;29(1):6-28.

13. Hsu CY, McCulloch CE, Iribarren $\mathrm{C}$, Darbinian J, Go AS. Body mass index and risk for end-stage renal disease. Annals of Internal Medicine. 2006;144(1):21-8.

14. Kurniawan LB, Bahrun U, Hatta M, Arif M. BMI and Waist Circumference Have Positive Correlation With Mitochondrial DNA Copy Number in Young Adult Male. The Open Obesity Journal. 2018;8(1):1-6.

15. Nakamura A, Shikata K, Nakatou T, Kitamura T, Kajitani N, Ogawa D, et al. Combination therapy with an angiotensin-convertingenzyme inhibitor and an angiotensin II receptor antagonist ameliorates microinflammation and oxidative stress in patients with diabetic nephropathy. Journal of Diabetes Investigation. 2013;4(2):195-201.

16. Di Cesar DJ, Ploutz-Snyder R, Weinstock RS, Moses AM. Vitamin D deficiency is more common in type 2 than in type 1 diabetes [6]. Diabetes Care. 2006;29(1):174.

17. Rodriques RA, Sulchan M. Kadar ProInflmator Sitokin Interleukin (IL)- 18 Pada Remaja Obesitas dengan Sindrom Metabolik. Journal of Nutrition College. 2014;3(3):40413.

18. Widiana IGR. Bali Uro-Nephrology Scientific Communication. Bali. 2017.

19. Lestari YA. Korelasi Obesitas Dengan Laju Filtrasi Glomerulus (Lfg) Di Rs Muhammadiyah Palembang. 2019.
20. Kawamoto R, Kohara K, Tabara Y, Miki T, Ohtsuka N, Kusunoki T, et al. An association between body mass index and estimated glomerular filtration rate. Hypertension Research. 2008;31(8):1559-64.

21. Malik RHA. Perbedaan Kadar Interleukin 18 pada pasien nefropati diabetik dan non nefropati diabetik. 2019.

22. Insani DA, Subagio HW, Hendrianingtyas M. Iron status and hepcidin levels as potential regulators of haemoglobin homeostasis in overweight and obese women of childbearing age. Journal of Taibah University Medical Sciences. 2019;14(6):531-7. 